\title{
DIFFICULTIES IN SYSTEMIC SCLEROSIS DIAGNOSIS ON THE EXAMPLE OF CLINICAL CASE
}

\author{
Golubkina E. O., Silenko I. Y., Brahmbhatt H.
}

Introduction. Systemic sclerosis (SSc) is a rare chronic systemic disease of the connective tissue, presenting with high level of patient-to-patient clinical variability of features.

Objectives. The aim of our research was to study a clinical case of the clinical course and difficulties in timely diagnosis of SSc in middle-age female patient.

Materials and methods. Patient is a 39 -year-old woman unemployed due to disability of 3rd degree. The disease manifested with Raynaud phenomenon in 2008. During 2008-2013 condition of the patient progressively worsened, new symptoms appeared as difficulty in swallowing of solid food, ulcers. In 2013 she was consulted by a surgeon and treated with antibiotics without significant effect. In October 2013 she was admitted to the rheumatology department, where she was eventually diagnosed with SSc, stage II (generalized), subacute course, activity II stage, with damage to the skin (edema, induration), blood vessels (Raynaud syndrome, stage III ischemia), joints (polyarthritis with predominant lesions of the hands, wrists, elbow, knee, feet joints, radiographic changes of II grade, functional impairment I st.), esophagus (esophagitis). The last hospitalization was due to the worsening of the general condition. Patient was treated with methylprednisolone $8 \mathrm{mg}$, amlodipine $2,5 \mathrm{mg}$, naftidrofuryl $200 \mathrm{mg}$ tid, aspirin $75 \mathrm{mg}$, pentoxifylline $600 \mathrm{mg}$, omeprazole $20 \mathrm{mg}$.

Results. Our study presents the results of different laboratory and instrumental tests conducted in the clinic: full blood count, biochemical panel, serological tests (antibodies), ECG, EchoCG, chest X-ray, upper Gl tract radiography, ultrasound of abdominal organs, kidneys, rheovasography of the vessels of the upper limbs, X-ray of hands. Patient was consulted by gastroenterologist, vascular surgeon and gynecologist.

Conclusions. An important task for the practicing physician is the ability to recognize the first signs of systemic sclerosis - "red flags", which will help to diagnose the disease at early stages, start timely treatment to prevent irreversible pathological changes, early disability and mortality of patients with SSc.

KEY WORDS: systemic sclerosis, Raynaud phenomenon, diagnosis difficulties

\section{INFORMATION ABOUT AUTHORS}

Golubkina Eugenia O., assistant of internal medicine department of V. N. Karazin Kharkiv National University, 6, Svoboda pl., Kharkiv, Ukraine, 61022, e-mail: golubkina.eugenia@ gmail.com, https://orcid.org/0000-0002-2587-8894

Silenko Iryna Y., assistant of internal medicine department of V. N. Karazin Kharkiv National University, 6, Svoboda pl., Kharkiv, Ukraine, 61022, e-mail: irinasilenko1980@ gmail.com, http://orcid.org/0000-0003-1732-0775

Brahmbhatt Harshkumar, student of medical faculty of V. N. Karazin Kharkiv National University, 6, Svoboda pl., Kharkiv, Ukraine, 61022, e-mail: Harshbarot6566@gmail.com

\section{INTRODUCTION}

Systemic sclerosis (SSc) is a rare chronic systemic disease of the connective tissue, presenting with generalized microangiopathy, immune dysregulation and fibrosis of skin and internal organs [1]. Features of SSc are high level of patient-to-patient clinical variability, multiple organ lesions and a progressive course leading to disability. The incidence of SSc varies from 2.3 to 10 people per 1 million. SSc usually appears in women aged 30-40 years with a female-to-male ratio of 3-6:1[2]. Etiology of SSc is not known. Pathogenesis of $\mathrm{SSc}$ is associated with excessive fibrosis, impaired microcirculation and the immune system dysregulation. An imbalance of cellular and humoral immunity is characteristic of SSc, leading to the activation of the synthesis of interleukins IL-1, IL-4, IL-6 and specific antinuclear antibodies (anticentromere antibodies, anti-Scl-70), antibodies to endothelium and connective tissue [3]. The main forms of systemic sclerosis are $[3,4]$ :

1. Diffuse systemic sclerosis(dSSc) involves skin thickening of the trunk and the extremities proximal to the elbows and knees besides involvement of the face;

2. Limited systemic sclerosis (ISSc) affects areas distal to the elbows and knees and also may involve the face and neck;

3. Systemic sclerosis sine scleroderma $(\mathrm{ssSSc})$ - there is internal organ involvement in the absence of clinically apparent cutaneous involvement;

The manifestation of SSc often begins with Raynaud phenomenon (RP), which in $70 \%$ of cases is the first clinical sign of SSc [1, 4]. The progression of RP leads to ischemic-trophic disorders: the formation of ulcers, as well as 
osteolysis. Skin lesions are specific for SSc and are divided into 3 phases: edematous, indurative and atrophic. Characteristic features of SSc are: mask-like face with radial furrowing around the mouth, skin tightening and tension, as well as sclerodactyly which is a hardening of the skin of the hands with increasing limitation of movements and the development of contractures [5]. The gastrointestinal tract lesions (dysphagia, gastroesophageal reflux disease) as well as the respiratory (pulmonary hypertension, interstitial lung fibrosis), renal (renal crisis, chronic renal failure), cardiovascular (myocardial fibrosis, arrhythmias, heart failure), musculoskeletal (arthralgia, myalgia, arthritis) and genitourinary (erectile dysfunction, bladder fibrosis) systems lesions are frequently involved in systemic sclerosis clinical presentation [4].

Diagnosis of SSc is based on criteria for the classification of systemic sclerosis that include features of clinical presentation (skin changes, RP, pulmonary lesions), serological tests (presence of systemic sclerosis-related autoantibodies), capillaroscopy abnormalities [6]. Treatment of SSc is based on the prescription of antifibrotic drugs (Dpenicillamine) in combination with arterial vasodilators, antiplatelet agents, non-steroidal anti-inflammatory drugs (NSAIDs), corticosteroids, disease-modifying antirheumatic drugs (DMARDs). Therapy of SSc also includes symptomatic treatment depending on the internal organs involvement [7].

\section{OUR CASE}

Female 39 years-old patient presented with complaints on pain and swelling of wrists more pronounced at night, lasting up to 5-6 hours, subsiding at rest with stiffness of wrists, inability to perform fine handwork; changing of skin color of hands to pale, then bluish that is aggravated in cold, chilliness and numbness of the hands and feet more pronounced in the cool season (due to this patient has to wear gloves and warm socks all the time); pain in knee and elbow joints with stiffness up to 2 hours. Also complains were of constant feeling of skin tightness especially on the face; inability to open mouth widely; changing of voice; difficulty of swallowing of solid foods, constant heartburn. Patient was concerned about periodical dyspnea on exertion; general weakness, fatigue, decreased muscle strength, hair loss and periodical fever up to $37.5^{\circ} \mathrm{C}$.
Patient also noted episodes of painless intermenstrual bleeding.

\section{ANAMNESIS OF THE DISEASE}

In year 2008 after childbirth patient first started to experience chilliness and numbness along with paleness and blueness of the fingers of both hands in the cold. She was consulted by district physician but diagnosis was not made and treatment was not prescribed; recommendations were to avoid hypothermia and wear gloves. In 2008-2013 condition of the patient progressively deteriorated, appeared pain in wrists, shoulder, knee, elbow joints, inability to perform fine handwork, difficulty in swallowing of solid food, feeling of skin tightness on the face, hair loss, changing of voice, weight loss. In January 2013 after URVI patient had a pronounced deterioration in her general condition: pain in the joints of the hands became more severe, appeared deep nonhealing ulcers on the fingertips. In September 2013 she was consulted by a surgeon with the diagnosis: Felon of the distal phalanx of the left thumb. Due to this patient was treated with antibiotics but without significant effect: full blood count showed significant increase of ESR $-42 \mathrm{~mm} /$ hour despite of the antibioticotherapy, the general condition of the patient did not improve. After non-successful treatment the patient was referred to rheumatologist and in October 2013 was admitted to the rheumatology department, where she was diagnosed with systemic sclerosis, stage II (generalized), subacute course, activity II stage, with damage to the skin (edema, induration), blood vessels (Raynaud syndrome, stage III ischemia), joints (polyarthritis with predominant lesions of the hands, wrists, elbow, knee, feet joints, radiographic changes of II grade, functional impairment I st.), esophagus (esophagitis). The patient was treated with methylprednisolone (20 mg/day). D-penicillamine was prescribed but the patient refused to use it due to her financial issues. Despite the treatment Raynaud phenomenon progressed and in December 2013 developed an osteolysis of the distal phalanx of the left thumb. Subsequently, the patient had planned hospitalization 2 times per year in a specialized rheumatology department. Takes constantly methylprednisolone, amlodipine, naftidrofuryl, aspirin. Last hospitalization was due to the worsening of the general condition (pain in 
wrists and cyanosis of the fingers became more pronounced).

\section{ANAMNESIS OF LIFE}

Patient is not working due to disability of $3^{\text {rd }}$ degree; denies smoking, alcohol abuse. Postponed diseases: URVI, pneumonia (May 2016); postponed operations: surgical treatment of cataract of both eyes (March 2016). Patient has mensis from 14 years old, also notes episodes of intermenstrual bleeding, which started 1 year ago; due to this she never had doctor's consult. Tuberculosis, diabetes mellitus, viral hepatitis, peptic ulcer, allergic reactions denies. Hereditary history is not burdened.

\section{OBJECTIVE EXAMINATION}

General condition of the patient is of moderate severity, clear consciousness, posture is active. Weight $-50 \mathrm{~kg}$, height $-164 \mathrm{~cm}$. BMI $-18,6 \mathrm{~kg} / \mathrm{m}^{2} ; \mathrm{t}-36.8^{\circ} \mathrm{C}$. Skin is pale, clean, dry, tightened; the patient has mask-like facial features, with poor mimic and radial furrowing around the mouth, incomplete opening of the mouth is observed. There is pallor, cyanosis of the skin of the hands and feet, their swelling, hardening of the skin, hypothermia. On the distal phalanges of the fingers - pitting scaring about 2-4 mm. Mucous membranes: pale-pink, tongue is covered with white plaque; lymphatic nodes are not palpated; peripheral edema is absent. Thyroid gland is not enlarged on palpation. Hoarseness of voice is present. Musculoskeletal system: hypothermia, cyanosis of the fingers; thickening, swelling and induration of the skin of the hands with smoothed contours of the metacarpophalangeal (MCP), carpometacarpal (CMC), wrist joints with pain on palpation, reduced muscular strength up to 3 points, limited flexion to $70 \%$. There is defect of distal phalanx of the left thumb and pitting scarring of the fingertips. Feet: hypothermia, cyanosis, puffiness, thickening, induration of the skin of the toes, tenderness to palpation. Other joints are not visually altered; there is no soft tissue swelling, change of skin color and skin temperature; slight tenderness on palpation of the knee and elbow joints. Range of movements in the joints is described below (see table 1).

Table 1

Range of movements in joints

\begin{tabular}{|l|l|l|l|l|}
\hline \multicolumn{1}{|c|}{ Types of movement } & \multicolumn{1}{c|}{ Wrist joints } & \multicolumn{1}{c|}{ Elbow joints } & Knee joints & Ankle joints \\
\hline Extension /flexion & $\begin{array}{l}\text { Right:45/40 } \\
\text { Left: } 50 / 40\end{array}$ & $\begin{array}{l}\text { Right: } 180 / 40 \\
\text { Left: } 175 / 40\end{array}$ & $\begin{array}{l}\text { Right: } 180 / 40 \\
\text { Left: } 180 / 40\end{array}$ & $\begin{array}{l}\text { Right:60/100 } \\
\text { Left:60/110 }\end{array}$ \\
\hline $\begin{array}{l}\text { Normal range } \\
\text { (extension/flexion) }\end{array}$ & $65 / 75$ & $180 / 40$ & $180 / 40$ & $70 / 130$ \\
\hline
\end{tabular}

Lungs: resonance percussion sound, on auscultation - harsh breathing over both lung fields, RR -18 . Heart borders on percussion are not enlarged, heart tones are clear, loud, rhythmic, HR -74 bpm; BP $-110 / 70$ on both arms, radial pulse is weakened, synchronous, rhythmic at $74 \mathrm{bpm}$. Abdomen: epigastric tenderness on palpation; liver is at the costal margin, painless; spleen is not palpable. Tapping sign is negative on both sides. Urination is free, painless.

\section{THE RESULTS OF CURRENT PATIENT'S INVESTIGATIONS}

- Full blood count: leukocytosis $14,8 * 10^{9} / \mathrm{L} \quad\left(\mathrm{N}-4,0-9,0 * 10^{9} / \mathrm{L}\right) ; \quad \mathrm{ESR}-$ $17 \mathrm{~mm} / \mathrm{h}(\mathrm{N}-2-15 \mathrm{~mm} / \mathrm{h})$; urinalysis - all parameters within the normal range;
- Biochemical panel (fasting plasma glucose, AST, ALT, urea, creatinine, total protein, calcium, potassium, sodium, chlorides, 25(OH)D, CRP, seromucoid) - CRP - $11 \mathrm{mg} / \mathrm{l}$ $(\mathrm{N}<5)$, other parameters within the normal range;

- Serological tests: positive ANA (antinuclear antibodies), positive anti-SS-A 52/60 with titer of $6.8 \mathrm{AI}(\mathrm{N}<1 \mathrm{AI})$, anti-Sm/RNP with titer of $8 \mathrm{AI}(\mathrm{N}<1 \mathrm{AI})$, anti-RNP- titer of $8 \mathrm{AI}$ ( $\mathrm{N}<1$ AI); anti-JO-1, anti-dsDNA, anti-Scl70, anti-centromere antibodies were negative;

- ECG: sinus rhythm, HR - 71 bpm, left anterior fascicular block of bundle of Hiss;

- EchoCG: chambers of the heart are not enlarged, myocardial contractility is satisfactory, ejection fraction $-58 \%$; 
- Chest X-ray: in lungs - infiltrative lesions are absent, sinuses of the lungs are without pathological changes, there are signs of pneumofibrosis, size and shape of the heart within normal limits;

- Upper Gl tract radiography: signs of gastroesophageal, duodenogastral reflux, esophagitis, sliding axial hernia of $1^{\text {st }}$ degree;

- Ultrasound of abdominal organs, kidneys: no pathological changes; ultrasound of the pelvic organs: echo signs of endometrial polyp;

- Rheovasography of the vessels of the upper limbs: in the left hand blood supply is reduced by $29 \%$, mild hypovolemia; in the right hand the blood supply is reduced by $34 \%$, moderate hypovolemia; the tone of large and medium arteries, the tone of small arteries, arterioles and venules in both hands is normal;

- X-ray of hands: bone defect in the distal phalanx of the left thumb; shortening, fuzziness of the adjacent interphalangeal joint plates of the left thumb with elements of marginal resorption; cystic restructuring of the heads of the metacarpal bones, patchy osteoporosis of the carpal bones (fig. 1).

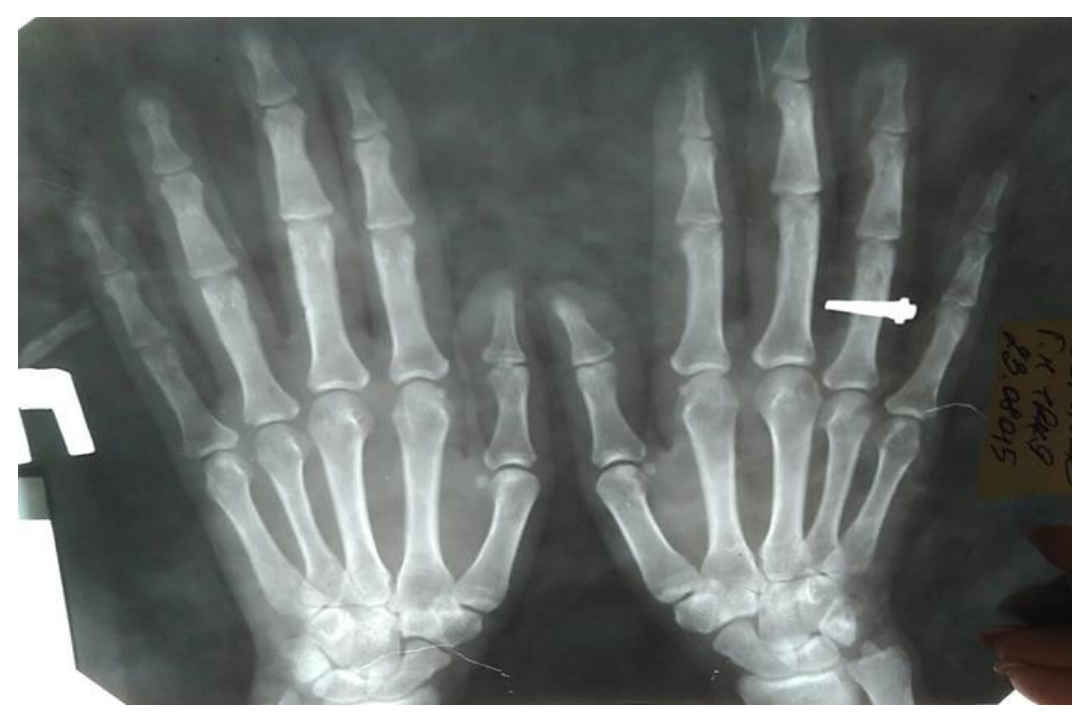

Fig. 1. X-ray of hands.

\section{CONSULTS OF SPECIALISTS}

- Consultation of gastroenterologist: gastroesophageal reflux, duodenogastral reflux, esophagitis, sliding axial hiatal hernia of $1^{\text {st }}$ degree.

- Consultation of vascular surgeon: Raynaud syndrome, chronic ischemia of III-rd degree.

- Consultation of gynecologist: endometrial polyp, recommended surgical intervention.

\section{DIAGNOSIS}

Main diagnosis: Systemic sclerosis, stage II (generalized), chronic course, activity of stage I, with skin lesions (edema, induration), vessels (Raynaud syndrome, ischemia of III degree), joints (polyarthritis with predominant lesion of the joints of the hands, wrists, feet, radiographic changes of II degree, functional impairment of I degree), esophagus (gastroesophageal, duodenogastric reflux, esophagitis, sliding axial hernia of 1 degree), lungs (pneumofibrosis).

Concomitant diagnosis: Polyp of endometrium.

\section{RECOMMENDATIONS AND TREATMENT}

Recommendations were to maintain healthy lifestyle, avoid physical overload, overcooling, insolation; diet with limitation of mechanical and chemical irritants, stimulants of gastric secretion, substances that linger for a long time in the stomach. Patient was advised to use moisturizing, emollient hypoallergenic skin care products.

Dynamic observation of specialists was recommended: rheumatologist, vascular surgeon, gastroenterologist, ophthalmologist, gynecologist, pulmonologist.

Drug therapy: methylprednisolone $8 \mathrm{mg}$ per day - constantly under the control of clinical and laboratory activity of the disease; 
naftidrofuryl hydrogen oxalate $200 \mathrm{mg} 3$ times a day for 3 months; pentoxifylline $600 \mathrm{mg} 1$ time per day - 2 months; amlodipine $2.5 \mathrm{mg} 1$ time a day - continuously under the BP control; aspirin $75 \mathrm{mg}$ after dinner - continuously; omeprazole $20 \mathrm{mg} 1$ time per day - from the 1st to the 10th day of each month.

Recommendations: spirometry and consultation of pulmonologist; surgical therapy for endometrial polyp: polypectomy.

\section{DISCUSSION}

Diagnosis of systemic sclerosis in the early stages has certain difficulties due to the poor specificity of the clinical picture, patients' underestimation of the severity of their condition, as well as low medical awareness for the identification of SSc [8]. According to studies [9], early signs of SSc include puffy, swollen fingers, Raynaud phenomenon, specific microvascular abnormalities by capillaroscopy and the presence of autoantibodies: ANA and specific for SSc anticentromere and antitopoisomerase-I antibodies. Presence of Raynaud phenomenon and puffy fingers are not often considered by patients as «serious symptoms» requiring a doctor's consultation. Due to research study [8] patients with kidney damage, difficulty breathing and ulcerative lesions of the fingers consulted the doctor almost immediately after the onset of these symptoms, while patients with Raynaud phenomenon sought medical help 6-9 months after the first complaints appeared. An important factor in the early diagnosis of SSc is the level of awareness of doctors, especially general practitioners, who are most often approached by patients with initial manifestations of systemic sclerosis. According to a study with interviewing of rheumatologists, dermatologists and general practitioners in Europe and America [8], it was found that there was low medical awareness for identifying SSc in general practitioners that along with an underestimation of the symptoms by the patients contributed to the late diagnosis of SSc. Another issue for timely diagnosis of SSc is that very early presentation of systemic sclerosis in most of the cases doesn't have sufficient features to fulfill the present classification criteria due to the American College of Rheumatology and European League Against Rheumatism [6, 10, 11].

SSc in our patient manifested in the form of Raynaud's phenomenon, however, during the initial examination, her symptoms were not regarded as signs of a rheumatic disease; further laboratory and instrumental investigations were not performed, which undoubtedly led to a late diagnosis of SSc. The diagnosis of SSc in our clinical case was made 5 years after the onset of the disease, when developed an overt clinical picture with lesions of the joints, blood vessels, gastrointestinal tract, and pronounced specific changes of the skin.

The tendency to the prevalence of late diagnosis of SSc is described by many authors $[9,10,12-13]$. It is obvious that the diagnosis of SSc in the late stages does not carry significant difficulties; mostly due to specific skin changes, as well as multiple organ lesions and vascular disorders [8]. However, the treatment of such patients in the later stages is limited because of: pronounced internal organs involvement, microvascular remodeling, tissue fibrosis or atrophy which are already irreversible [9]. Severe complications of SSc such as renal crisis, interstitial pulmonary fibrosis and pulmonary hypertension, ischemic limb lesions and osteolysis often lead to disability and increased mortality of these patients [4].

While treatment in the early stages of SSc allows to slow down and control the progression of the disease and to prevent irreversible pathological changes and thus avoid the disability of the patients $[9,11,14]$. Despite the fact that early signs of SSc such as Raynaud phenomenon and swollen puffy fingers have low specificity, they were suggested to be considered as «red flags» for a general practitioner, which will allow suspicion of SSc and further serological and instrumental studies aimed at early detection of this disease [11].

\section{CONCLUSIONS}

Diagnosis of systemic sclerosis in our patient was made a 5 years after the onset of symptoms mainly due to weak medical vigilance in detection of rare rheumatologic diseases, as a result late diagnosis in this case led to untimely prescribed treatment and to the disability of the patient. An important task for the practicing physician is the ability to recognize the first signs of systemic sclerosis «red flags», which will help to diagnose the disease at early stages, start timely treatment to prevent irreversible pathological changes, early disability and mortality of patients with SSc. 


\section{REFERENCES}

1. Системна склеродермія: клініка, діагностика, лікування [electronicresource] / [О.М. Біловол, Князькова I.I.] // Внутренняя медицина. - 2008. - № 1 (7). - Access to resourse: http://www.mifua.com/archive/article/4383.

2. Systemic sclerosis [electronic resource] / [R. A. Schwartz, A. Zalewska] // Medscape. - 2019. - Access to resourse: https://emedicine.medscape.com/article/1066280-overview\#showall.

3. Шостак Н. А., Клименко А. А. Системная склеродермия: современная классификация и методы лечения/ Н. А. Шостак, А. А. Клименко // Лечебное дело. - 2009. - № 4. - s. 4-11.

4. Scleroderma [electronic resource] / [S. A. Jimenez, F. A. Mendoza] // Medscape. - 2018. - Access to resourse: https://emedicine.medscape.com/article/331864-overview\#showall.

5. Старовойтова М. Н. Поражение кожи при системной склеродермии / М. Н. Старовойтова // Научнопрактическая ревматология. - 2010. - № 2. - s. 83-86.

6. Van den Hoogen F. 2013 classification criteria for systemic sclerosis: an American college of rheumatology/European league against rheumatism collaborative initiative. / F. van den Hoogen, D. Khanna, J. Fransen [et al.] // Ann Rheum Dis. - 2013. - № 72. - p. 1747-1755.

7. Клінічний протокол надання медичної допомоги хворим із системною склеродермією (ССД) // Український ревматологічний журнал. - 2007. - № 1 (27). - p. 80.

8. Distler O. Factors influencing early referral, early diagnosis and management in patients with diffuse cutaneous systemic sclerosis / O. Distler, Y. Allanore, C. P. Denton [et al.] // Rheumatology. - 2018. № 7. - p. 813-817.

9. Bellando Randone S. Very early diagnosis of systemic sclerosis / S.Bellando Randone, S. Guiducci, M. Matucci-Cerinic // Pol Arch Med Wewn. - 2012. - № 122 (Suppl 1.). - p. 18-23.

10. Vrancken A. Difficulties in diagnosis of systemic sclerosis-related interstitial lung disease / AnniekVrancken, Ellen De Langhe, Rene Westhovens [et al.] // Respirology Case Reports. - 2015. № (3). - p. 99-101.

11. Very early and early diagnosis of systemic sclerosis [electronic resource] / [G. Lepri, S.Bellando Randone, C. Bruni [et al.]] // Future Medicine. - 2013. - Access to resourse: https://www.futuremedicine.com/doi/full/10.2217/ebo.13.169.

12. Bellando-Randone S. Patient subgroups and potential risk factors in systemic sclerosis: is there a possibility of an early diagnosis? / S.Bellando Randone, S. Guiducci, M. Matucci-Cerinic // Int. J. Clin. Rheumatol. - 2010. - № 5 (5). - p. 555-564.

13. Meyer O. C. Disease subsets, antinuclear antibody profile, and clinical features in 127 French and 247 US adult patients with systemic sclerosis. / O. C. Meyer, N. Fertig, M. Lucas [et al.] // The Journal of Rheumatology. - 2007. - Vol.34 (№ 1). - p. 104-109.

14. Hudson M. Time to Diagnosis in Systemic Sclerosis: Is Sex a Factor? / M.Hudson, B. Thombs, M. Baron// Pol Arthritis \& Rheumatism (Arthritis Care \& Research). - 2009. -Vol.61 (№ 2). - p. 274-278.

\section{REFERENCES}

1. Bilovol, O. M., Kniazkova, I. I. Cystemna sklerodermiia: klinika, diahnostyka, likuvannia [electronic resource] // Vnutrenniaia medytsyna. 2008. 1(7). Access to resourse: http://www.mif-ua.com/archive/ article/4383. (in Ukrainian)

2. Schwartz, R. A., Zalewska, A., Systemic sclerosis [electronic resource] // Medscape. - 2019. - Access to resourse: https://emedicine.medscape.com/article/1066280-overview\#showall.

3. Shostak, N. A., Klimenko, A. A. Sistemnaya sklerodermiya: sovremennaya klassifikatsiya i metodyi lecheniya // Lechebnoe delo. 2009. 4. P. 4-11. (in Russian)

4. Jimenez, S. A., Mendoza, F. A. Scleroderma [electronic resource] // Medscape. 2018. Access to resourse: https://emedicine.medscape.com/article/331864-overview\#showall.

5. Starovoytova, M. N., Porazhenie kozhi pri sistemnoy sklerodermii // Nauchno-prakticheskaya revmatologiya. 2010. 2. P. 83--86. (in Russian)

6. Van den Hoogen, F., Khanna, D. Fransen, J. [et al.] 2013 classification criteria for systemic sclerosis: an American college of rheumatology / European league against rheumatism collaborative initiative. // Ann Rheum Dis. 2013. 72. - P. 1747-1755.

7. Klinichnyi protokol nadannia medychnoi dopomohy khvorym iz systemnoiu sklerodermiieiu (SSD) // Ukrainskyi revmatolohichnyi zhurnal. 2007. 1 (27). P. 80. (in Ukrainian)

8. Distler, O., Allanore, Y., Denton, C. P. [et al.] Factors influencing early referral, early diagnosis and management in patients with diffuse cutaneous systemic sclerosis // Rheumatology. 2018. 57. P. 813-817.

9. Bellando, Randone, S., Guiducci, S., Matucci-Cerinic, M. Very early diagnosis of systemic sclerosis // Pol Arch Med Wewn. 2012. 122 (Suppl 1.). P. 18-23 
10. Vrancken A., De Langhe E., Westhovens R. [et al.] Difficulties in diagnosis of systemic sclerosis-related interstitial lung disease // Respirology Case Reports. 2015. 3 (3). P. 99-101.

11. Lepri, G., Bellando, Randone, S., Bruni C. [et al.] Very early and early diagnosis of systemic sclerosis [electronic resource] // Future Medicine. 2013. Access to resourse: https://www.futuremedicine.com/doi/full/10.2217/ebo.13.169.

12. Bellando Randone, S., Guiducci, S., Matucci-Cerinic, M. Patient subgroups and potential risk factors in systemic sclerosis: is there a possibility of an early diagnosis? // Int. J. Clin. Rheumatol. 2010. 5 (5). P. 555-564.

13. Meyer, O. C., Fertig, N., Lucas, M. [et al.] Disease subsets, antinuclear antibody profile, and clinical features in 127 French and 247 US adult patients with systemic sclerosis. // The Journal of Rheumatology. 2007. Vol.34 (1). P. 104-109.

14. Hudson, M., Thombs, B., Baron, M. Time to Diagnosis in Systemic Sclerosis: Is Sex a Factor? // Pol Arthritis \& Rheumatism (Arthritis Care \& Research). 2009. Vol.61 (2). - P. 274-278.

\section{СКЛАДНОСТІ У ДІАГНОСТИЦІ СИСТЕМНОЇ СКЛЕРОДЕРМІЇ НА ПРИКЛАДІ КЛІНІЧНОГО ВИПАДКУ}

\section{Голубкіна С. О., Сіленко І. Ю., Брахмбхатm Х.}

Вступ. Системна склеродермія (СС) - це рідкісне хронічне системне захворювання сполучної тканини, що характеризується високим рівнем клінічної варіабельності ознак від пацієнта до пацієнта.

Мета. Метою нашого дослідження стало вивчення клінічного випадку перебігу і труднощів в своєчасній діагностиці СС у пацієнтки середнього віку.

Матеріали та методи. Пацієнтка - 39-річна жінка, безробітна 3 приводу інвалідності 3-го ступеня. Захворювання проявилося феноменом Рейно в 2008 році. Протягом 2008-2013 років стан хворої прогресивно погіршувався, з\&\#39;явилися нові симптоми - труднощі з ковтанням твердої їжі, виразки. У 2013 році ії проконсультував хірург, вона пройшла курс антибіотикотерапії без значного ефекту. У жовтні 2013 року госпіталізована в ревматологічне

відділення, де їй нарешті був поставлений діагноз СС, II стадія (генералізована), підгострий перебіг, II стадія активності, з пошкодженням шкіри (набряк, ущільнення), кровоносних судин (синдром Рейно, стадія III ішеміі), суглобів (поліартрит з переважним ураженням рук, зап\&39;ясть, ліктьового, колінного, суглобів стоп, рентгенологічні зміни II ступеня, функціональні порушення І ст.), стравоходу (езофагіт). Остання госпіталізація була пов\&\#39;язана 3 погіршенням загального стану. Пацієнтка отримувала метилпреднізолон 8 мг, амлодипін 2,5 мг, нафтідрофуріл 200 мг три рази на день, аспірин 75 мг, пентоксифілін 600 мг, омепразол 20 мг.

Результати. У нашому дослідженні представлені результати різних лабораторних та інструментальних тестів, проведених в лікарні: загальний аналіз крові, біохімічна панель, серологічні тести (антитіла), ЕКГ, ЕхоКГ, рентгенографія грудної клітки, рук і верхніх відділів шлунково-кишкового тракту, УЗД органів черевної порожнини, нирок, реовазографія судин верхніх кінцівок. Пацієнтку консультували гастроентеролог, судинний хірург і гінеколог.

Висновки. Важливим завданням для практикуючого лікаря $\epsilon$ вміння розпізнати перші ознаки СС - «червоні прапори», які допоможуть діагностувати захворювання на ранніх стадіях, розпочати своєчасне лікування для запобігання незворотних патологічних змін, ранньої непрацездатності та смертності пацієнтів з СС.

КЛЮЧОВІ СЛОВА: системна склеродермія, феномен Рейно, складності діагностики

\section{IНФОРМАЦІЯ ПРО АВТОРІВ}

Голубкіна Євгенія Олександрівна, асистент кафедри внутрішньої медицини Харківського національного університету імені В. Н. Каразіна, пл. Свободи, 6, Харків, Україна, 61022, e-mail: golubkina.eugenia@gmail.com, https://orcid.org/0000-0002-2587-8894

Сіленко Ірина Юріївна, асистент кафедри внутрішньої медицини Харківського національного університету імені В. Н. Каразіна, пл. Свободи, 6, Харків, Україна, 61022, e-mail: irinasilenko1980@ gmail.com,

http://orcid.org/0000-0003-1732-0775

Брахмбхатт Харшкумар, студент 6 курсу медичного факультету Харківського національного університету імені В. Н. Каразіна, пл. Свободи, 6, Харків, Україна, 61022, e-mail: Harshbarot6566@gmail.com

\section{СЛОЖНОСТИ В ДИАГНОСТИКЕ СИСТЕМНОЙ СКЛЕРОДЕРМИИ НА ПРИМЕРЕ КЛИНИЧЕСКОГО СЛУЧАЯ}

\section{Голубкина Е. А., Силенко И. Ю., Брахмбхатт Х.}

Вступление. Системная склеродермия (СС) - это редкое хроническое системное заболевание соединительной ткани, характеризующееся высоким уровнем клинической вариабельности признаков от пациента к пациенту.

Цель. Целью нашего исследования стало изучение клинического случая течения и трудностей в своевременной диагностике СС у пациентки среднего возраста. 
Материалы и методы. Пациентка - 39-летняя женщина, безработная из-за инвалидности 3-й степени. Заболевание проявилось феноменом Рейно в 2008 году. В течение 2008-2013 годов состояние больной прогрессивно ухудшалось, появились новые симптомы - трудности с глотанием твердой пищи, язвы. В 2013 году ее проконсультировал хирург, она прошла курс антибиотикотерапии без значительного эффекта. В октябре 2013 года была госпитализирована в ревматологическое отделение, где ей в конечном итоге был поставлен диагноз СС, II стадия (генерализованная), подострое течение, II стадия активности, с повреждением кожи (отек, уплотнение), кровеносных сосудов (синдром Рейно, стадия III ишемии), суставов (полиартрит с преимущественным поражением рук, запястий, локтевого, коленного, суставов стоп, рентгенологические изменения II степени, функциональные нарушения I ст.), пищевода (эзофагит). Последняя госпитализация была связана с ухудшением общего состояния. Пациентка получала метилпреднизолон 8 мг, амлодипин 2,5 мг, нафтидрофурил 200 мг три раза в день, аспирин 75 мг, пентоксифиллин 600 мг, омепразол 20 мг.

Результаты. В нашем исследовании представлены результаты различных лабораторных и инструментальных тестов, проведенных в больнице: общий анализ крови, биохимическая панель, серологические тесты (антитела), ЭКГ, ЭхоКГ, рентгенография грудной клетки, рук и верхних отделов желудочно-кишечного тракта, УЗИ органов брюшной полости, почек, реовазография сосудов верхних конечностей. Пациентку консультировали гастроэнтеролог, сосудистый хирург и гинеколог.

Выводы. Важной задачей для практикующего врача является умение распознать первые признаки СС «красные флаги», которые помогут диагностировать заболевание на ранних стадиях, начать своевременное лечение для предотвращения необратимых патологических изменений, ранней нетрудоспособности и смертности пациентов с СС.

КЛЮЧЕВЫЕ СЛОВА: системная склеродермия, феномен Рейно, сложности диагностики

\section{ИНФОРМАЦИЯ ОБ АВТОРАХ}

Голубкина Евгения Александровна, ассистент кафедры внутренней медицины Харьковского национального университета имени В. Н. Каразина, пл. Свободы, 6, Харьков, Украина, 61022, e-mail: golubkina.eugenia@gmail.com, https://orcid.org/0000-0002-2587-8894

Силенко Ирина Юрьевна, ассистент кафедры внутренней медицины Харьковского национального университета имени В.Н.Каразина, пл. Свободы, 6, Харьков, Украина, 61022, e-mail: irinasilenko1980@ gmail.com, http://orcid.org/0000-0003-1732-0775

Брахмбхатт Харшкумар, студент 6 курса медицинского факультета Харьковского национального университета имени В. Н. Каразина, пл. Свободы, 6, Харьков, Украина, 61022, e-mail: Harshbarot6566@ gmail.com 